\title{
Larval nematodes found in amphibians from northeastern Argentina
}

\author{
González, CE.* and Hamann, MI.* \\ Centro de Ecología Aplicada del Litoral, Consejo Nacional de Investigaciones Científicas y Técnicas, \\ Ruta Provincial 5, Km 2,5, W 3400 AMD, Corrientes, Argentina \\ *e-mail: cynthyaelizabethg@hotmail.com, monika_hamann@yahoo.com \\ Received July 27, 2009 - Accepted September 28, 2009- Distributed November 30, 2010
}

(With 11 figures)

\begin{abstract}
Five species of amphibians, Leptodactylus podicipinus, Scinax acuminatus, S. nasicus, Rhinella fernandezae and Pseudis paradoxa, were collected in Corrientes province, Argentina and searched for larval nematodes. All larval nematodes were found as cysts in the serous of the stomach of hosts. Were identified one superfamily, Seuratoidea; one genus, Spiroxys (Superfamily Gnathostomatoidea) and one family, Rhabdochonidae (Superfamily Thelazioidea). We present a description and illustrations of these taxa. These nematodes have an indirect life cycle and amphibians are infected by consuming invertebrate, the intermediate hosts. The genus Spiroxys and superfamily Seuratoidea were reported for the first time for Argentinean amphibians.
\end{abstract}

Keywords: larval nematodes, amphibians, Argentina.

\section{Larvas de nematoides encontradas em anfíbios no nordeste da Argentina}

\begin{abstract}
Resumo
Cinco espécies de anfíbios, Leptodactylus podicipinus, Scinax acuminatus, S. nasicus, Rhinella fernandezae e Pseudis paradoxa, foram coletadas na província de Corrientes, Argentina e pesquisadas para achar nematoides larvais. Todas as larvas foram encontradas como cisto na serosa do estômago dos hospedeiros. Foram identificadas uma superfamília, Seuratoidea, um gênero, Spiroxys (Superfamília Gnathostomatoidea) e uma família, Rhabdochonidae (Superfamília Thelazioidea). Apresentamos uma descrição e ilustrações dos táxons. Estes nematoides têm um ciclo de vida indireto e os anfíbios são infectados pelo consumo dos invertebrados, os hospedeiros intermediários. O gênero Spiroxys e a superfamília Seuratoidea são relatados pela primeira vez para anfíbios da Argentina.
\end{abstract}

Palavras-chave: larvas de nematoides, anfíbios, Argentina.

\section{Introduction}

Adult amphibians play an important role in the life cycle of different species of nematode parasites, principally when they act as paratenic hosts. Studies of nematodes in Argentinean amphibians showed larval stages in different families of these vertebrates, such as Physaloptera Rudolphi, 1819 that it found in gastric mucosa of families Bufonidae, Leptodactylidae and Leiuperidae (Gutierrez et al., 2005; González and Hamann, 2006a,b, 2007a, 2008), Contracaecum Railliet and Henry, 1912 found in mesentery of Hyla nana Boulenger, 1889 and Serpinema cf. trispinosum found in the intestine of Lysapsus limellum Cope, 1862 (Hamann and Kehr, 1998; González and Hamann, 2007b). All of these nematodes require the presence of an invertebrate intermediate host in their life cycle.

The main goal of this study was to report the larval stage of nematode parasites of the superfamilies Seuratoidea Hall, 1916, Gnathostomatoidea Railliet, 1895 and, Thelazioidea Sobolev, 1949 in naturally infected amphibians from northeastern Argentina. We also present a description and illustrations of these taxa.

\section{Material and Methods}

The amphibians studied were collected near the city of Corrientes, Province of Corrientes, Argentina $\left(27^{\circ} 28^{\prime} \mathrm{S}\right.$ and $\left.58^{\circ} 50^{\prime} \mathrm{W}\right)$ between January 2002 and November 2008. They were hand-captured, preferentially at night, using the sampling technique defined as "visual encounters survey" (Crump and Scott, 1994). A total of 74 specimens of the following 5 species were examined: Leptodactylus podicipinus (Cope, 1862) $(\mathrm{n}=6)$, Scinax acuminatus (Cope, 1862) ( $\mathrm{n}=6)$, S. nasicus (Cope, 1862) $(\mathrm{n}=49)$, Rhinella fernandezae (Gallardo, 1957) $(\mathrm{n}=10)$ and Pseudis paradoxa (Linnaeus, 1758) $(\mathrm{n}=3)$. Hosts were transported live to the laboratory and euthanised in a chloroform $\left(\mathrm{CHCL}_{3}\right)$ solution. At necropsy the alimentary canal, lungs, liver, kidneys, urinary bladder, coelomic 
cavity, musculature, and integument were examined for parasites by dissection. Cyst were counted and isolated from host tissues. Larvae were removed from cysts using preparation needles and studied either in vivo, counted, then killed in hot distilled water, preserved in $70 \%$ ethyl alcohol, cleared in glycerine or lactophenol, and examined as temporary mounts. Drawings were prepared by use of a Zeiss microscope with a camera lucida. Measurements are given in micrometres $(\mu \mathrm{m})$ unless otherwise stated. Infection prevalence and intensity were calculated according to Bush et al. (1997). Nematodes were deposited in the Colección Helmintológica of the Centro de Ecología Aplicada del Litoral, Corrientes, Argentina (CECOAL).

\section{Results and Discussion}

A total of 28 nematodes were collected from 74 amphibians examined. In L. podicipinus and in $R$. fernandezae were found nematodes of superfamily Seuratoidea; in P. paradoxa nematodes of superfamily Gnathostomatoidea and, in Scinax spp. nematodes of superfamily Thelazioidea.

\section{Descriptions}

Superfamily: Seuratoidea Hall, 1916

Seuratoidea gen. sp. (Figures 1-4)

Prevalence and intensity: 33.0\%; 3 (L. podicipinus), 40.0\%; 14 ( $R$. fernandezae).

Voucher material: CECOAL 08100104.

Larvae $(\mathrm{n}=5)$ : body whitish 2.1-2.62 mm long and 85-110 wide; cuticle with very fine transverse striations. Cephalic end rounded, bearing four distinct circumoral papillae and a pair of lateral amphids present. Short mouth tube present. Oesophagus muscular throughout, distinctly expanded near its posterior end; length of oesophagus 260-280, width of its anterior part 15-22 at its expanded posterior part 42-60. Nerve ring 125-140 from anterior end. Excretory pore 160-210 from anterior end. Intestine light-coloured, relatively wide. Rectum a narrow hyaline tube; small round rectal glands present. Tail conical, 95-110 long, with sharply pointed tip. Each larva was spirally coiled inside a cyst. Cysts almost spherical, brownish, thin-walled, measures were 800$1000 \times 660-700$.

Comments: for morphological characteristics as lips on head end strongly reduced, oral opening oval shaped and, oesophagus muscular throughout, its posterior half broader than anterior half; this larva belongs to the superfamily Seuratoidea. Moravec and Kaiser (1995) found a similar larva in eleuterodactylids from Central America. Some metric characteristic of this study are lower, e.g., length of body: 3.52-3.65 mm; length of oesophagus: 294-354; nerve ring from anterior end: 186-210 and others are greater, e.g., excretory pore from anterior end: 0.96-120; tail: 159-171.

Unfortunately, knowledge of the transmission and development of species of superfamily Seuratoidea are very limited. The life cycle of most species involve intermediate host (Anderson, 2000). Puylaert (1970) found third stage larvae of this superfamily, in chironomids in the stomach of Xenopus laevis (Daudin, 1802) from Africa.

Superfamily: Gnathostomatoidea Railliet, 1895

Family: Gnathostomatidae Railliet, 1895

Genus: Spiroxys Schneider, 1866

Spiroxys sp. (Figures 5-8)

Prevalence and intensity: $33.3 \% ; 3$ (P. paradoxa) Voucher material: CECOAL 08112501

Larvae $(\mathrm{n}=1)$ : small nematodes with finely transversaly striated cuticle. Length of body $1.97 \mathrm{~mm}$, maximum width 75. Cephalic end provided with two triangular lateral pseudolabia. Two cephalic papillae and one small amphid present on either side at level of base of pseudolabia. Walls of oral opening weakly sclerotized. Stoma weakly developed, very short. Oesophagus starting at level of base of pseudolabia. Oesophagus divided into narrow, anterior muscular part (length 100) and broader posterior glandular part (length 620). Excretory pore 200 from anterior end. Intestine brownish, straight. Tail conical, 82 long, with rounded tip. Cyst almost spherical, measures were 380-400 x 350-375.

Comments: the identification of these larvae is based mainly on the characteristic large lateral triangular pseudolabia. The metrical characteristics of the specimens studied here correspond to those provided by Moravec et al. (1995) from larvae analized in fishes of Mexico (e.g. length of body: 2.03-2.17 mm; length of muscular oesophagus: 129-135; length of glandular oesophagus: 555-675).

Adult stage of genus Spiroxys parasite stomach of different species of freshwater turtles. Female nematodes expelled eggs with the turtle's faeces and the first-stage larvae develop in them. Then, it is ingested by a copepod and, in the haemocoel of this invertebrate, attains its third stage. Infective larvae of Spiroxys were found in various potential paratenic hosts, among them, snails, tadpoles and adults frogs and, larval and adult of newts (Anderson, 2000).

\section{Superfamily: Thelazioidea Sobolev, 1949}

Family: Rhabdochonidae Travassos, Artigas and Pereira, 1928

Rhabdochonidae gen. sp. (Figures 9-11)

Prevalence and intensity: 17.0\%; 1 (S. acuminatus); 6.0\%; 7 (S. nasicus)

Voucher material: CECOAL 04101101.

Larvae $(n=8)$ : length of body $1.4-3.32 \mathrm{~mm}$, maximum width 90-115. Pseudolabia practically absent. Oral opening round, two lateral amphids. Stoma (vestibule) cylindrical, elongated, dilated anteriorly. Prostom 17-27 long and 18-23 wide. Length of vestibule (including prostom) 104-155, of muscular oesophagus 210-360, of glandular oesophagus 1.01-1.30 mm. Deirids well developed, bifurcate, situated near mid-length of vestibule, 80-115 from 

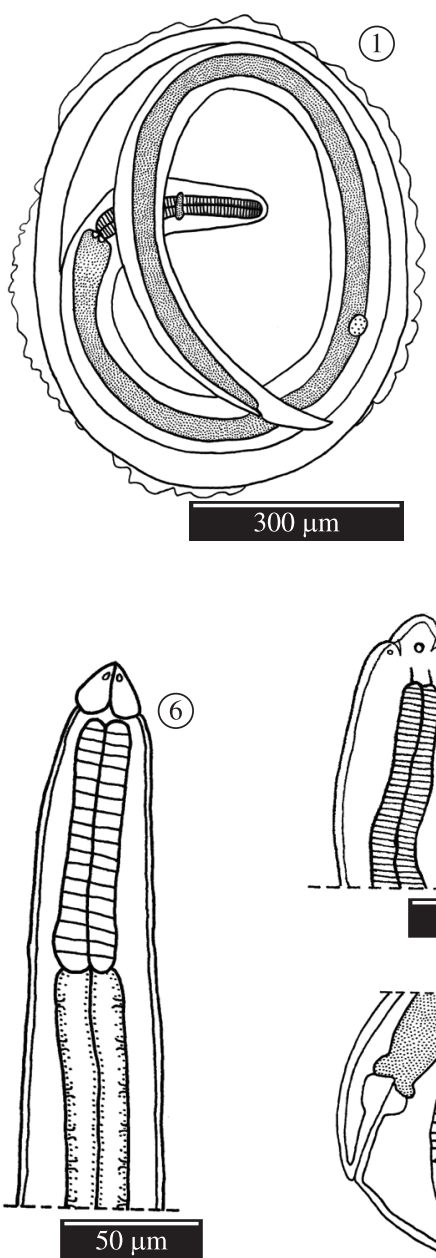
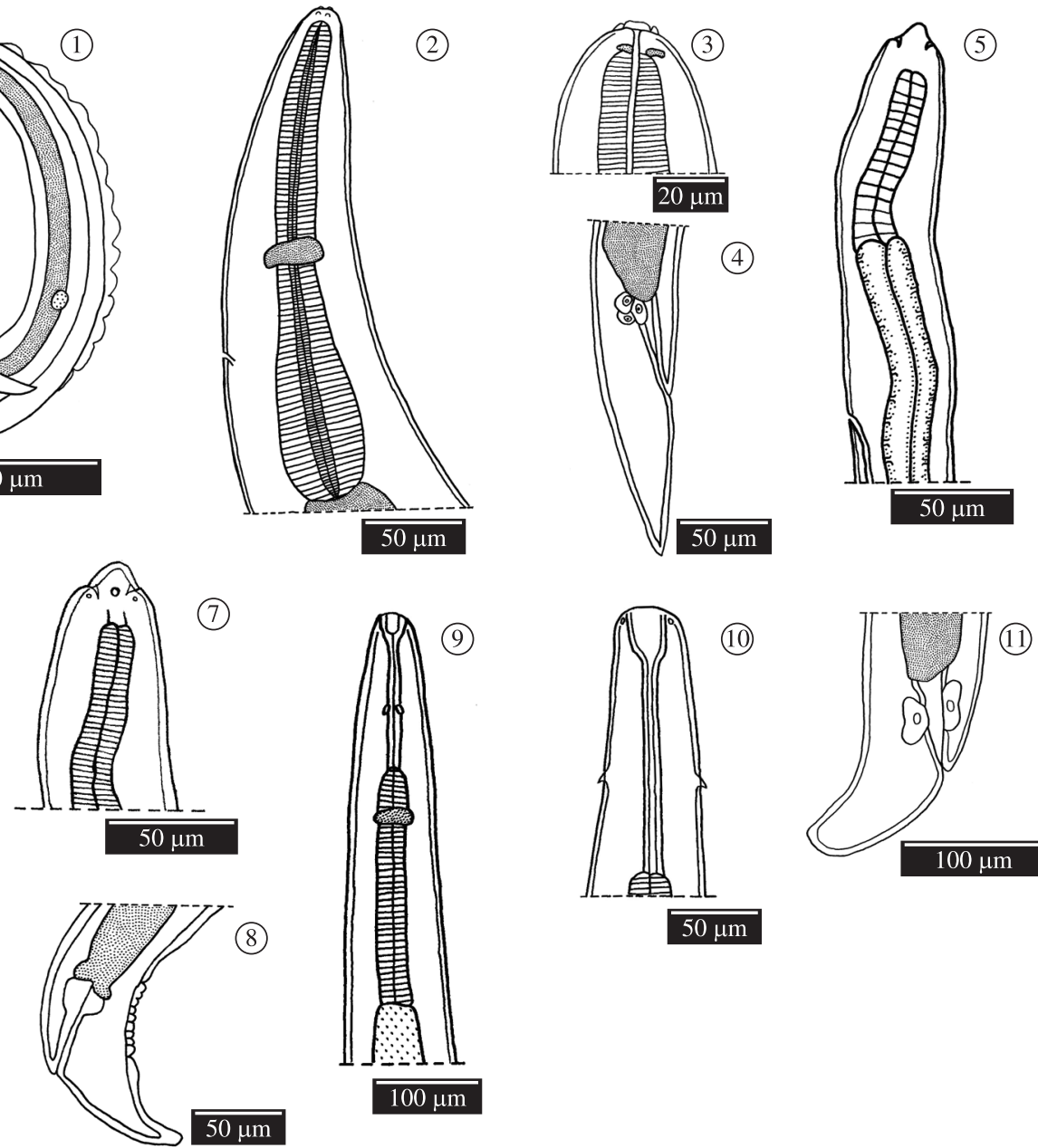

Figures 1-11. Nematode parasites in larval stage found in amphibians from Corrientes, Argentina. Seuratoidea gen. sp. 1) Cyst. 2) Anterior extremity, lateral view 3). Cephalic end, detail. 4) Posterior extremity, lateral view. Spiroxys sp. 5) Anterior extremity, lateral view. 6) Anterior extremity, dorsal view. 7) Cephalic end, detail. 8) Posterior extremity, lateral view. Rhabdochonidae gen. sp. 9) Anterior extremity, dorsal view. 10) Cephalic end, detail. 11) Posterior extremity, lateral view. (1, 2, 4 collected from $L$. podicipinus; 3, collected from $R$. fernandezae; 9, 11 collected from $S$. acuminatus; 10 collected from $S$. nasicus). Scale bars: $1=300 \mu \mathrm{m} ; 2,4,5,6,7,8,10=50 \mu \mathrm{m} ; 3=20 \mu \mathrm{m} ; 9,11=100 \mu \mathrm{m}$.

anterior end. Excretory pore 220 from anterior end (not observed in larvae found in S. nasicus). Intestine bright orange. Nerve ring encircling muscular oesophagus 150-200 from anterior end of body. Tail conical, 110-150 long, with rounded tip. Cyst almost spherical, measures were $500 \times 425$.

Comments: the identification of these larvae is mainly based on the presence of stoma elongated with an anterior dilatation that forms a well-defined funnel and, for the presence of long glandular oesophagus, approximately 5 times as long as the muscular one. The nematode described here showed the vestibule without thickenings or teeth, in accordance with that observed by Moravec and Kaiser (1994) in adults rhabdochonids found in Central America.

The members of family Rhabdochonidae are parasites of the digestive tract, the abdominal cavity and some internal organs especially of cold-blooded vertebrate; are rare in mammals. Amphipods and, especially, ephemeropters act as intermediate hosts. Within this family, the genus Rhabdochona has been the subject of numerous studies regarding the life cycle (Anderson, 2000). Previous records of nematodes belonging to this family in amphibians are the species Trichospirura amphibiophila Moravec and Kaiser, 1994, found in abdominal cavity (encapsulated near the liver) from Eleutherodactylus martinicencis (Tschudi, 1838) in the French Antilles (Moravec and Kaiser, 1994) and unknown rhabdochonid species found in S. nasicus from Corrientes, Argentina (Hamann et al., 2009).

Previously, for these amphibians, we have reported different groups of helminth parasites, e.g. adults and larval nematodes from $R$. fernandezae and S. acuminatus (González and Hamann, 2007a, 2008); adults and larvae 
of trematodes, nematodes and acanthocephalan from $S$. nasicus (Hamann and González, 2009; Hamann et al., 2009); adults and larvae trematodes and nematodes from P. paradoxa (Kehr and Hamann, 2003). In this paper we presented five species of amphibians that can act as paratenic or intermediate hosts of three taxa of nematodes. These amphibians are consumed by other vertebrates due to their small size and its soft body and, therefore, most of them could be an important source of infection for the definitive hosts.

The genus Spiroxys and superfamily Seuratoidea were reported for the first time for Argentinean amphibians.

\section{References}

ANDERSON, RC., 2000. Nematode Parasites of Vertebrates: Their Development and Transmission. $2^{\text {nd }}$ ed. Wallingford, Oxon, UK: CABI Publishing.

BUSH, AO., LAFFERTY, KD., LOTZ, JM. and SHOSTAK, W., 1997. Parasitology meets ecology on its own terms: Margolis et al. revisited. Journal of Parasitology, vol. 83, no. 4, p. 575-583.

CRUMP, ML. and SCOTT Jr, NJ., 1994. Visual encounters surveys. In HEYER, WR., DONNELLY, MA., MC-DIARMID, RW., HAYEK, LC. and FOSTER, MS. (Eds.). Measuring and monitoring biological diversity - Standard methods for amphibians. Washington, D.C.: Smithsonian Institution Press, p. 84-91.

GONZÁLEZ, CE. and HAMANN, MI., 2006a. Helmintos parásitos de Leptodactylus bufonius Boulenger, 1894 (Anura: Leptodactylidae) de Corrientes, Argentina. Revista Española de Herpetología, vol. 20, p. 39-46.

-, 2006b. Nematodes parásitos de Chaunus granulosus major (Müller \& Hellmich, 1936) (Anura: Bufonidae) en Corrientes, Argentina. Cuadernos de Herpetología, vol. 20, no. 1, p. 43-49.

-, 2007a. Nematode parasites of two species of Chaunus (Anura: Bufonidae) from Corrientes, Argentina. Zootaxa, vol. 1393, p. 27-34.

-, 2007b. The first record of amphibians as paratenic host of Serpinema larvae (Nematoda: Camallanidae). Revista Brasileira de Biologia = Brazilian Journal of Biology, vol. 67, no. 3, p. 579-580.
-, 2008. Nematode parasites of two anurans species, Rhinella schneideri (Bufonidae) and Scinax acuminatus (Hylidae), from Corrientes, Argentina. Revista de Biología Tropical, vol. 56, no. 4 , p. $2147-2161$

GUTIERREZ, C., ATTADEMO, A., GUERRERO, S., PELTZER, P. and LAJMANOVICH, R., 2005. Physalaemus biligonigerus (False-eyed Frog). Endoparasites. Herpetological Review, vol. 36, no. 2, p. 161-162.

HAMANN, MI. and GONZÁLEZ, CE., 2009. Larval digenetic trematodes in tadpoles of six amphibian species from Northeastern Argentina. Journal of Parasitology, vol. 95, no. 3, p. 623-628.

HAMANN, MI. and KEHR, AI., 1998. Variación espacio temporal en infrapoblaciones de helmintos y su relación con las fluctuaciones poblacionales de Hyla nana (Anura, Hylidae). Cuadernos de Herpetología, vol. 12, no. 2, p. 23-33.

HAMANN, MI., KEHR, AI., GONZÁLEZ, CE., DURÉ, MI. and SCHAEFER, EF., 2009. Parasite and reproductive features of Scinax nasicus (Anura: Hylidae) from a South American subtropical area. Interciencia, vol. 34, no. 3, p. 214-218.

KEHR, AI. and HAMANN, MI., 2003. Ecological Aspects of Parasitism in the Tadpole of Pseudis paradoxa from Argentina. Herpetological Review, vol. 34, no. 4, p. 336-341.

MORAVEC, F. and KAISER, H., 1994. Trichospirura amphibiophila n. sp. (Nematoda: Rabdochonidae) in the frog Eleutherodactylus martinicensis from La Désirade, French Antilles. Journal of Parasitology, vol. 80, no. 1, p. 121-125.

-, 1995. Helminth Parasites from West Indian Frogs, with Description of Two New Species. Caribbean Journal of Science, vol. 31, no. 3-4, p. 252-268.

MORAVEC, F., VIVAS-RODRIGUEZ, C., SCHOLZ, T., VARGASVÁZQUEZ, J., MENDOZA-FRANCO, E., SCHMITTER-SOTO, JJ. and GONZÁLEZ-SOLÍS, D. 1995. Nematodes parasitic in fishes of cenotes (= sinkholes) of the Peninsula of Yucatan, Mexico. Part 2. Larvae. Folia Parasitologica, vol. 42, p. 199-210.

PUYLAERT, FA., 1970. Description de Chitwoodchabaudia skryabini g.n., sp. n. (Chitwood-Chabaudiidae fam. nov.), parasite de Xenopus laevis victorianus Ahl. (Cosmocercoidea - Nematoda - Vermes). Revue de Zoologie et de Botanique Africaines, vol. 81, p. 369-382. 